\title{
Pittosporum poumense
}

\author{
Assessment by: Gemmill, C., Veillon, J.-M., Amice, R., Cazé, H., Dumontet, V., \\ Fleurot, D., Garnier, D., Gâteblé, G. \& Maggia, L.
}

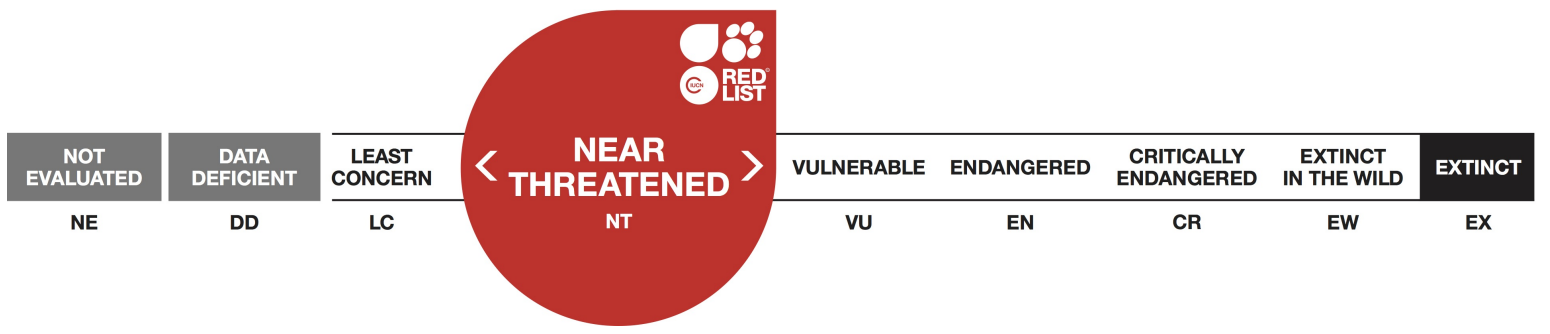

View on www.iucnredlist.org

Citation: Gemmill, C., Veillon, J.-M., Amice, R., Cazé, H., Dumontet, V., Fleurot, D., Garnier, D., Gâteblé, G. \& Maggia, L. 2017. Pittosporum poumense. The IUCN Red List of Threatened Species 2017: e.T82948742A82951892. http://dx.doi.org/10.2305/IUCN.UK.20173.RLTS.T82948742A82951892.en

Copyright: (C) 2017 International Union for Conservation of Nature and Natural Resources Reproduction of this publication for educational or other non-commercial purposes is authorized without prior written permission from the copyright holder provided the source is fully acknowledged.

Reproduction of this publication for resale, reposting or other commercial purposes is prohibited without prior written permission from the copyright holder. For further details see Terms of Use.

The IUCN Red List of Threatened Species ${ }^{T M}$ is produced and managed by the IUCN Global Species Programme, the IUCN Species Survival Commission (SSC) and The IUCN Red List Partnership. The IUCN Red List Partners are: Arizona State University; BirdLife International; Botanic Gardens Conservation International; Conservation International; NatureServe; Royal Botanic Gardens, Kew; Sapienza University of Rome; Texas A\&M University; and Zoological Society of London. 


\section{Taxonomy}

\begin{tabular}{|c|c|c|c|c|}
\hline Kingdom & Phylum & Class & Order & Family \\
\hline Plantae & Tracheophyta & Magnoliopsida & Rosales & Pittosporaceae \\
\hline
\end{tabular}

Taxon Name: Pittosporum poumense Guillaumin

\section{Taxonomic Source(s):}

Tirel, Ch. and Veillon, J.-M. 2002. Flore de la Nouvelle-Calédonie, tome 24. Pittosporaceae. Museum d'Histoire Naturelle, Paris.

\section{Assessment Information}

Red List Category \& Criteria: $\quad$ Near Threatened ver 3.1

Year Published:

Date Assessed:
2017

July 23, 2015

\section{Justification:}

Endemic small tree of New Caledonia, Pittosporum poumense is a species mostly found on the west coast from Bourail to Poum with a disjunction to the east coast near the Thio area (type-locality for this species). Pittosporum poumense is found in shrubland from sea level to $800 \mathrm{~m}$ asl., mostly on serpentine alluvium. Its area of occupancy and extent of occurrence are equal to 244 and 3,347 $\mathrm{km}^{2}$ respectively for a total of around twenty localities (=locations). Among threats linked to projected continuous decline of habitat are : mining activities, bushfires, and invasive species such as Rusa Deer and feral pigs. Using criterion B, P. poumense is assessed as Near Threatened (NT) as it is close to qualifying for a threatened category (VU) B1ab(iii)+2ab(iii).

\section{Geographic Range}

\section{Range Description:}

Endemic small tree of New Caledonia, Pittosporum poumense is a species mostly found on west coast from Bourail to Poum with a disjunction to the east coast near the Thio area (type-locality for this species).

\section{Country Occurrence:}

Native: New Caledonia 


\section{Distribution Map}

\section{Pittosporum poumense}
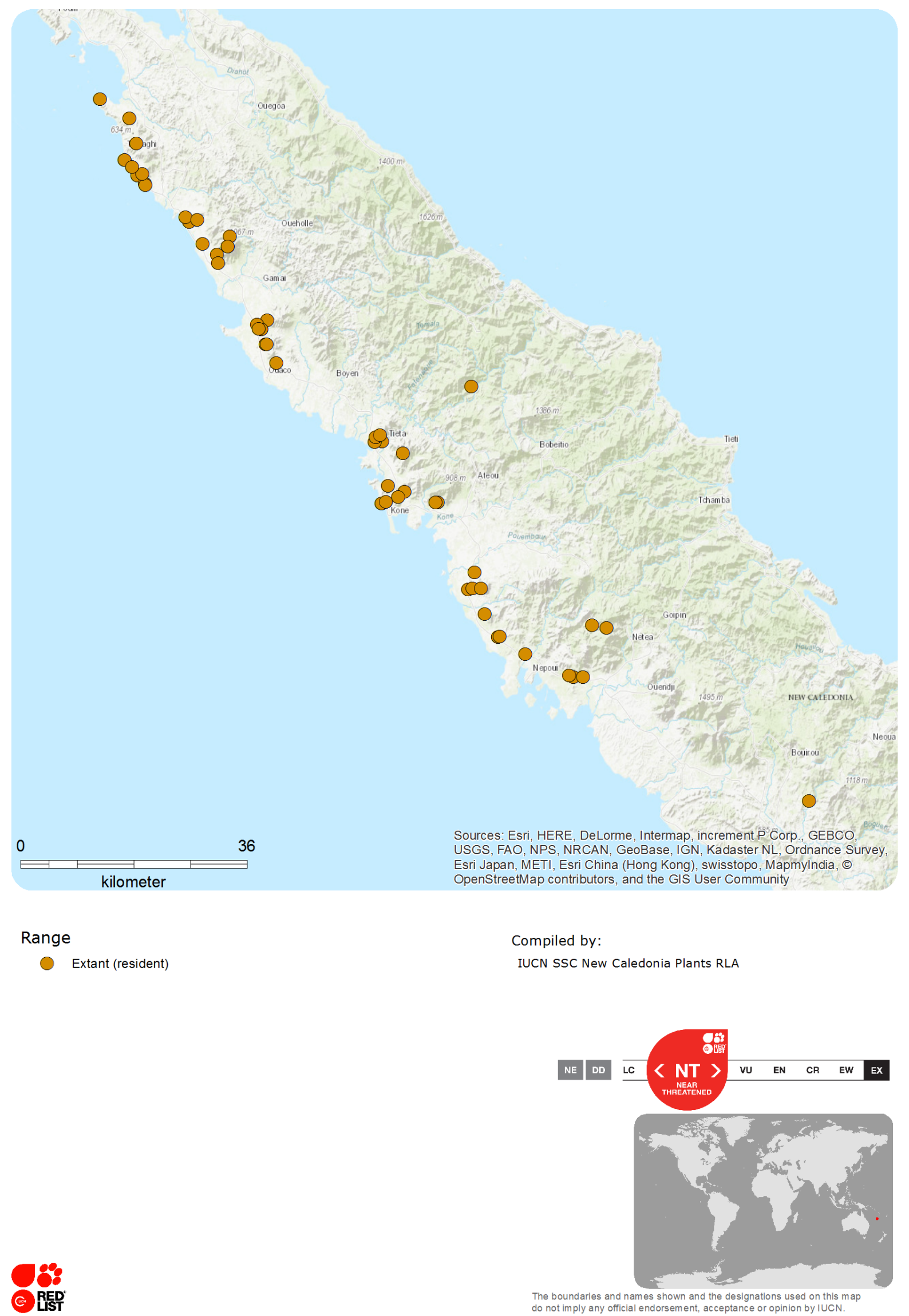


\section{Population}

Population size is unknown.

Current Population Trend: Decreasing

\section{Habitat and Ecology (see Appendix for additional information)}

P. poumense is found in shrubland from sea level to $800 \mathrm{~m}$ asl., mostly on serpentine alluvial.

Systems: Terrestrial

\section{Threats (see Appendix for additional information)}

The main threats related to the decline of habitat quality of Pittosporum poumense are caused by mining activities, fire and invasive animal species such as Rusa Deer (Rusa timorensis), wild pigs, as well as induced water stress by environmental changes. New Caledonia contains between $20-30 \%$ of the world's nickel resources. Intense mining activities since the late 19th century has generated soil erosion (1.2\% of bare ground mapped by SPOT5 in 2007).

\section{Conservation Actions (see Appendix for additional information)}

Pittosporum poumense is not protected by any legislation and is not known from any protected area. The type specimen collected from Thio described by Balansa raises questions because it is the sole collection on the east coast. Field surveys of this area and/or detailed study on origin of this type are required. According to recent genetic studies, populations of Boulinda, Pindaï, Poum and Tinip show genetic differences. Those populations depict a continuum of genetic variability, which support the need for specific conservation measures for each subpopulation to be established.

\section{Credits}

Assessor(s): $\quad$ Gemmill, C., Veillon, J.-M., Amice, R., Cazé, H., Dumontet, V., Fleurot, D., Garnier, D., Gâteblé, G. \& Maggia, L.

Reviewer(s): $\quad$ Tanguy, V.

Facilitators(s) and Chanfreau, S.

Compiler(s): 


\section{Bibliography}

Endemia.nc. 2016. Faune et Flore de Nouvelle-Calédonie. Available at: http://www.endemia.nc.

Gomez, C., Mangeas, M., Curt, T., Ibanez, T., Munzinger, J., Dumas, P., Jérémy, A., Despinoy, M. and Hély, C. 2014. Wildfire risk for main vegetation units in a biodiversity hotspot: modeling approach in New Caledonia, South Pacific. Ecology and Evolution 5(2): 377-390. DOI: 10.1002/ece3.1317.

Hély-Alleaume. 2012. INC : Incendies et biodiversité des éco-systèmes en Nouvelle-Calédonie.

IUCN. 2017. The IUCN Red List of Threatened Species. Version 2017-3. Available at: www.iucnredlist.org. (Accessed: 7 December 2017).

L'Huillier, L., Jaffré, T. and Wulff, A. 2010. Mines et Environnement en Nouvelle-Calédonie: les milieux sur substrats ultramafiques et leur restauration. IAC, Nouméa.

Tirel, Ch. and Veillon, J.-M. 2002. Flore de la Nouvelle-Calédonie, tome 24. Pittosporaceae. Museum d'Histoire Naturelle, Paris.

\section{Citation}

Gemmill, C., Veillon, J.-M., Amice, R., Cazé, H., Dumontet, V., Fleurot, D., Garnier, D., Gâteblé, G. \& Maggia, L. 2017. Pittosporum poumense. The IUCN Red List of Threatened Species 2017: e.T82948742A82951892. http://dx.doi.org/10.2305/IUCN.UK.2017-3.RLTS.T82948742A82951892.en

\section{Disclaimer}

To make use of this information, please check the Terms of Use.

\section{External Resources}

For Images and External Links to Additional Information, please see the Red List website. 


\section{Appendix}

\section{Habitats}

(http://www.iucnredlist.org/technical-documents/classification-schemes)

\begin{tabular}{|c|c|c|c|}
\hline Habitat & Season & Suitability & $\begin{array}{l}\text { Major } \\
\text { Importance? }\end{array}$ \\
\hline 3. Shrubland -> 3.5. Shrubland - Subtropical/Tropical Dry & - & Suitable & - \\
\hline
\end{tabular}

\section{Threats}

(http://www.iucnredlist.org/technical-documents/classification-schemes)

\begin{tabular}{|c|c|c|c|c|}
\hline Threat & Timing & Scope & Severity & Impact Score \\
\hline \multirow{2}{*}{$\begin{array}{l}\text { 11. Climate change \& severe weather }->11.2 \text {. } \\
\text { Droughts }\end{array}$} & Ongoing & - & - & - \\
\hline & Stresses: & \multicolumn{3}{|c|}{ 1. Ecosystem stresses $\rightarrow>1.2$. Ecosystem degradation } \\
\hline \multirow{3}{*}{$\begin{array}{l}\text { 3. Energy production \& mining }->3.2 \text {. Mining \& } \\
\text { quarrying }\end{array}$} & Ongoing & - & - & - \\
\hline & Stresses: & \multirow{2}{*}{\multicolumn{3}{|c|}{$\begin{array}{l}\text { 1. Ecosystem stresses }->1.1 \text {. Ecosystem conversion } \\
\text { 1. Ecosystem stresses }->1.2 \text {. Ecosystem degradation }\end{array}$}} \\
\hline & & & & \\
\hline \multirow{4}{*}{$\begin{array}{l}\text { 7. Natural system modifications }->7.1 \text {. Fire } \& \text { fire } \\
\text { suppression }->7.1 .1 \text {. Increase in fire } \\
\text { frequency/intensity }\end{array}$} & Ongoing & - & - & - \\
\hline & Stresses: & \multirow{3}{*}{\multicolumn{3}{|c|}{$\begin{array}{l}\text { 1. Ecosystem stresses }->1 \text { 1.1. Ecosystem conversion } \\
\text { 1. Ecosystem stresses }->1.2 \text {. Ecosystem degradation } \\
\text { 2. Species Stresses }->2.1 \text {. Species mortality }\end{array}$}} \\
\hline & & & & \\
\hline & & & & \\
\hline \multirow{4}{*}{$\begin{array}{l}\text { 8. Invasive and other problematic species, genes } \& \\
\text { diseases }->8.1 \text {. Invasive non-native/alien } \\
\text { species/diseases }->8.1 .2 \text {. Named species (Sus } \\
\text { domesticus) }\end{array}$} & Ongoing & - & - & - \\
\hline & Stresses: & \multirow{3}{*}{\multicolumn{3}{|c|}{$\begin{array}{l}\text { 1. Ecosystem stresses }->1.2 \text {. Ecosystem degradation } \\
\text { 2. Species Stresses }->2.2 \text {. Species disturbance } \\
\text { 2. Species Stresses }->2.3 \text {. Indirect species effects }-> \\
\text { 2.3.7. Reduced reproductive success }\end{array}$}} \\
\hline & & & & \\
\hline & & & & \\
\hline \multirow{5}{*}{$\begin{array}{l}\text { 8. Invasive and other problematic species, genes } \& \\
\text { diseases }->8.1 \text {. Invasive non-native/alien } \\
\text { species/diseases }->8.1 .2 \text {. Named species (Rusa } \\
\text { timorensis) }\end{array}$} & Ongoing & - & - & - \\
\hline & Stresses: & \multirow{4}{*}{\multicolumn{3}{|c|}{$\begin{array}{l}\text { 1. Ecosystem stresses }->1.2 \text {. Ecosystem degradation } \\
\text { 2. Species Stresses }->2.1 \text {. Species mortality } \\
\text { 2. Species Stresses }->2.2 \text {. Species disturbance } \\
\text { 2. Species Stresses }->2.3 \text {. Indirect species effects }-> \\
\text { 2.3.7. Reduced reproductive success }\end{array}$}} \\
\hline & & & & \\
\hline & & & & \\
\hline & & & & \\
\hline
\end{tabular}

\section{Conservation Actions in Place}

(http://www.iucnredlist.org/technical-documents/classification-schemes) 


\begin{tabular}{|l|}
\hline Conservation Actions in Place \\
\hline In-Place Land/Water Protection and Management \\
\hline Occur in at least one PA: No \\
\hline Invasive species control or prevention: No \\
\hline In-Place Species Management \\
\hline Successfully reintroduced or introduced beningly: No \\
\hline Subject to ex-situ conservation: No \\
\hline
\end{tabular}

\title{
Research Needed
}

(http://www.iucnredlist.org/technical-documents/classification-schemes)

\author{
Research Needed \\ 1. Research -> 1.1. Taxonomy
}

\section{Additional Data Fields}

\begin{tabular}{|l|}
\hline Distribution \\
\hline Estimated area of occupancy (AOO) ( $\left.\mathrm{km}^{2}\right): 244$ \\
\hline Continuing decline in area of occupancy (AOO): No \\
\hline Extreme fluctuations in area of occupancy (AOO): No \\
\hline Estimated extent of occurrence (EOO) (km²): 3347 \\
\hline Continuing decline in extent of occurrence (EOO): No \\
\hline Extreme fluctuations in extent of occurrence (EOO): No \\
\hline Number of Locations: 1-20 \\
\hline Continuing decline in number of locations: No \\
\hline Extreme fluctuations in the number of locations: No \\
\hline Lower elevation limit (m): 1 \\
\hline Upper elevation limit (m): 800 \\
\hline Population \\
\hline Continuing decline of mature individuals: No \\
\hline Extreme fluctuations: No \\
\hline Population severely fragmented: No \\
\hline No. of subpopulations: 1-20 \\
\hline Extreme fluctuations in subpopulations: No \\
\hline
\end{tabular}


Habitats and Ecology

Continuing decline in area, extent and/or quality of habitat: Yes

Generation Length (years): 0 


\section{The IUCN Red List Partnership}

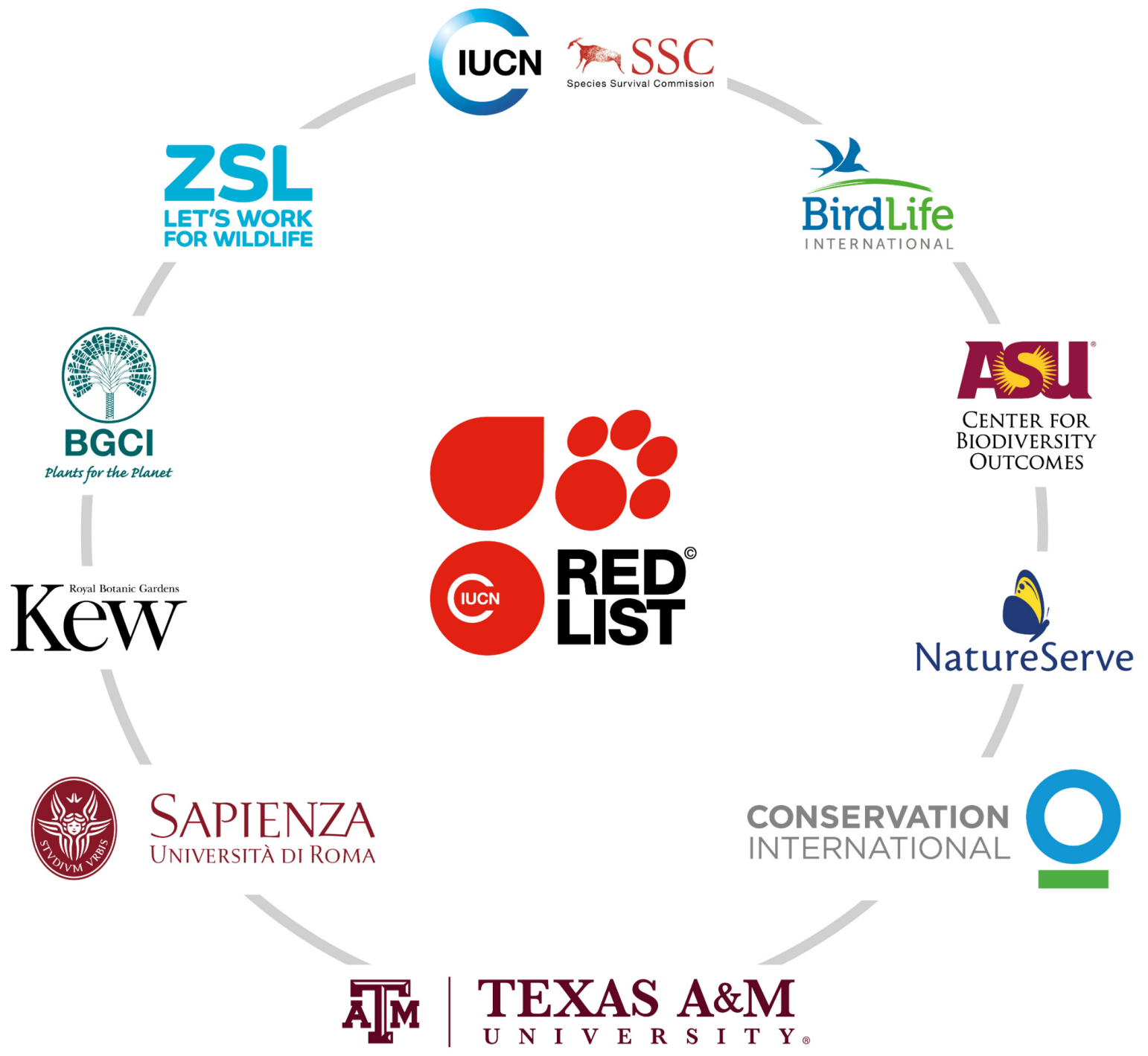

The IUCN Red List of Threatened Species ${ }^{\mathrm{TM}}$ is produced and managed by the IUCN Global Species Programme, the IUCN Species Survival Commission (SSC) and The IUCN Red List Partnership.

The IUCN Red List Partners are: Arizona State University; BirdLife International; Botanic Gardens Conservation International; Conservation International; NatureServe; Royal Botanic Gardens, Kew; Sapienza University of Rome; Texas A\&M University; and Zoological Society of London. 